University of South Florida

DIGITAL COMMONS

Digital Commons @ University of

@ UNIVERSITY OF SOUTH FLORIDA

South Florida

$1-1-2014$

\title{
2014 Work Plan USF St. Petersburg
}

USF

Follow this and additional works at: https://digitalcommons.usf.edu/usf_accountability_reports

\section{Scholar Commons Citation}

USF, "2014 Work Plan USF St. Petersburg" (2014). USF Accountability Reports. 46.

https://digitalcommons.usf.edu/usf_accountability_reports/46

This Article is brought to you for free and open access by the USF Archives at Digital Commons @ University of South Florida. It has been accepted for inclusion in USF Accountability Reports by an authorized administrator of Digital Commons @ University of South Florida. For more information, please contact digitalcommons@usf.edu. 


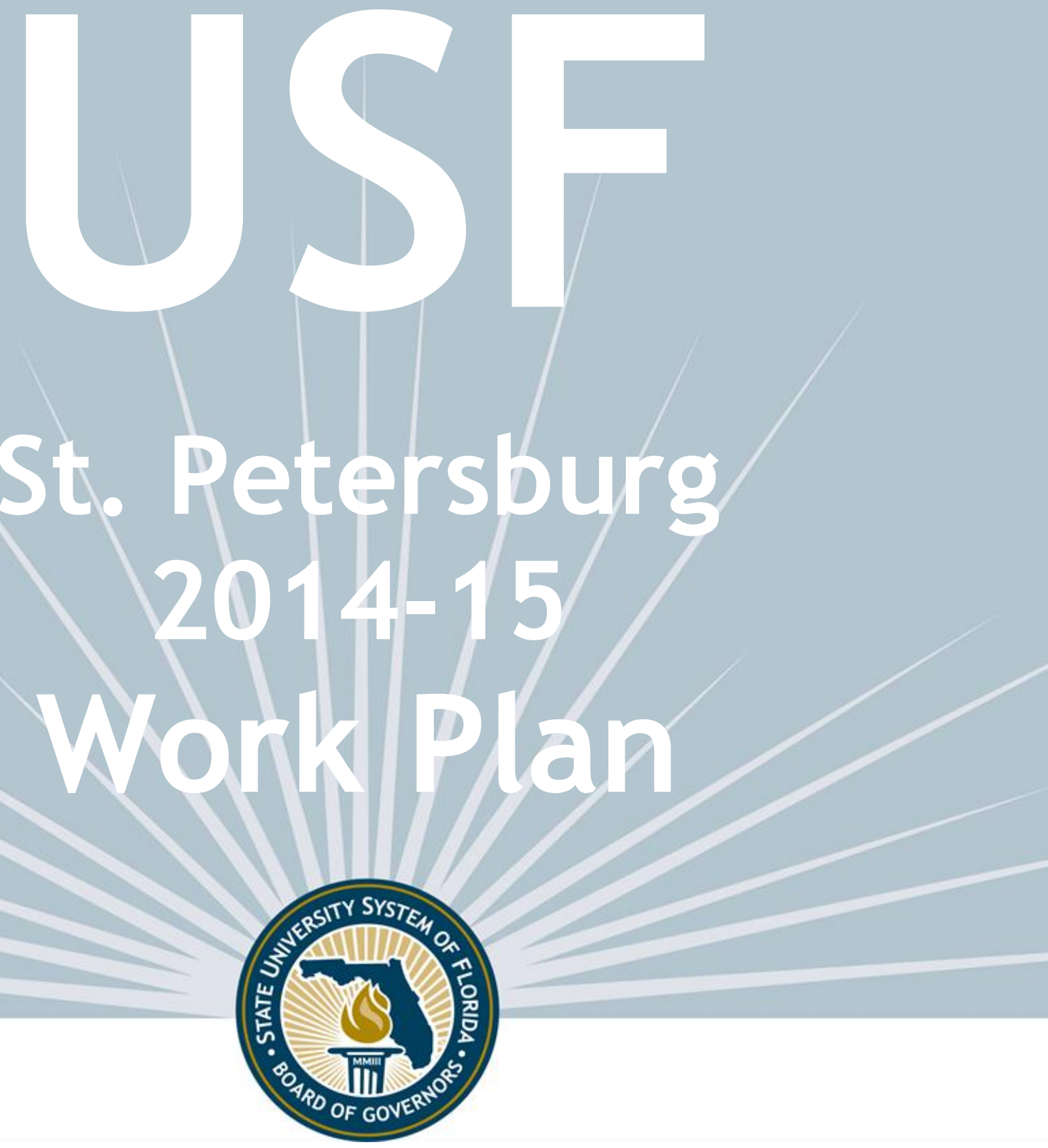

University of South Florida St. Petersburg

Work Plan Presentation for 2014-15 Board of Governors Review

STATE UNIVERSITY SYSTEM of FLORIDA $\mid$ Board of Governors 


\section{INTRODUCTION}

The State University System of Florida has developed three tools that aid in guiding the System's future.

1) The Board of Governors' new Strategic Plan 2012-2025 is driven by goals and associated metrics that stake out where the System is headed;

2) The Board's Annual Accountability Report provides yearly tracking for how the System is progressing toward its goals;

3) Institutional Work Plans connect the two and create an opportunity for greater dialogue relative to how each institution contributes to the System's overall vision.

These three documents assist the Board with strategic planning and with setting short-, mid-and long-term goals. They also enhance the System's commitment to accountability and driving improvements in three primary areas of focus: 1) academic quality, 2) operational efficiency, and 3) return on investment.

The Board will use these documents to help advocate for all System institutions and foster even greater coordination with the institutions and their Boards of Trustees.

Once a Work Plan is approved by each institution's respective Boards of Trustees, the Board of Governors will review and consider the plan for potential acceptance of 2014-15 components. Longer-term components will inform future agendas of the Board's Strategic Planning Committee. The Board's acceptance of a work plan does not constitute approval of any particular component, nor does it supersede any necessary approval processes that may be required for each component. 


\section{TABLE OF CONTENTS}

\section{STRATEGY}
a. Mission Statement
b. Vision Statement
c. Statement of Strategy
d. Strengths and Opportunities
e. Key Initiatives \& Investments

\section{PERFORMANCE BASED FUNDING METRICS}

\section{PREEMINENT RESEARCH UNIVERSITY METRICS}

\section{OTHER KEY PERFORMANCE INDICATORS}
a. Goals Common to All Universities
b. Goals Specific to Research Universities
c. Institution Specific Goals

\section{OPERATIONS}
a. Fiscal Information (includes Tuition Differential Fee Request)
b. Enrollment Planning
c. Academic Program Coordination

\section{DEFINITIONS}




\section{MISSION STATEMENT (What is your purpose?)}

The University of South Florida St. Petersburg offers distinctive graduate and undergraduate programs in the arts and sciences, business, and education within a close -knit, student -centered learning community that welcomes individuals from the region, state, nation and world. We conduct wideranging, collaborative research to meet society's needs and engage in service projects and partnerships to enhance the university and community's social, economic and intellectual life. As an integral and complementary part of a multi-institutional system, USF St. Petersburg retains a separate identity and mission while contributing to and benefiting from the associations, cooperation, and shared resources of a premier national research university.

\section{VISION STATEMENT (What do you aspire to?)}

The University of South Florida St. Petersburg will be a premier master's degree level urban university recognized for its vibrant community of scholars who engage and improve the community.

\section{STATEMENT OF STRATEGY (How will you get there?)}

\section{Given your mission, vision, strengths and available resources, provide a brief description of your} market and your strategy for addressing and leading it.

While presently guided by USFSP's current strategic plan, mission and vision, our strategies are also informed by the ongoing strategic planning process for 2014-2019, Vision 20/20. To achieve USFSP's goal of creating a distinctive identity as a top teaching and research institution, USFSP will emphasize faculty scholarship and research, student performance and discovery, campus culture, and strategic partnerships. USFSP will pursue these goals by providing the organizational infrastructure and the sustainable funding to make this possible. Throughout this process, USFSP's top priority is student success through increased student retention and graduation rates.

It will measure its success through a combination of internal and external measures, including academic performance, student retention, degree completion, campus culture, employment after graduation, national recognition of faculty excellence, and increased external funding. Recognized by the Carnegie Foundation for the Advancement of Teaching as a community-engaged institution, USFSP will also continue to emphasize and assess civic engagement. 


\section{STRENGTHS AND OPPORTUNITIES (within 3 years)}

\section{What are your core capabilities, opportunities and challenges for improvement?}

USFSP's core capabilities include excellence in teaching using all forms of delivery, high levels of faculty-student interaction, faculty achievement, entrepreneurial spirit, strong and collaborative community engagement, key partnerships, and data-based decision-making. USFSP provides students with an intimate intellectual environment to facilitate their growth as active learners and instill life-long habits of the mind. USFSP has high potential for carefully planned and managed growth in enrollment as it retains its institutional character of close faculty-student interactions.

Beginning with Fall of 2014, USFSP expect undergraduate enrollments to grow by 3 percent each year over the next three years for FTIC and transfer students, with concomitant growth in graduate enrollments. The recruitment and retention of full-time FTIC students will continue to be a focused effort. The institution's strengths (residential character of the campus, partnership with USF System, high quality of faculty and programs, undergraduate research opportunities, dynamic waterfront location) will make USFSP a "first choice" for those living in Pinellas County and beyond. In addition, transfer students are an important market for this institution. USFSP will continue to work with St. Petersburg College to provide the last two years of a college degree for those who are location-bound. The campus's close proximity to major employers (HSN, Jabil Circuits, Raymond James, All Children's Hospital, Bayfront Medical Center) make the institution an ideal partner for working adults seeking to pursue master degrees in information technology, financial services, and allied health. Responding to the employment needs/gaps identified by industry partners and the BOG, USFSP will create and provide access to high demand programs.

Increased emphasis on campus culture and enhanced opportunities for student engagement provide strategic opportunities for improvement, particularly with retention and graduation rates. As our STEM programs prosper, we have growing demands for teaching and laboratory space, as well as financial aid for a student population that is increasingly needy.

\section{KEY INITIATIVES \& INVESTMENTS (within 3 years)}

Describe your top three key initiatives for the next three years that will drive improvement in Academic Quality, Operational Efficiency, and Return on Investment.

1. Provide the requisite physical, human, and technological infrastructure for USFSP to sustain its current areas of excellence and to grow by design.

- Enhance current facilities to support current and future extant programs and faculty and student needs, including classrooms, laboratories, studios, and the student service corridor.

- Assess and enhance infrastructure for career development, internships, partnerships, community engagement, and the experience for freshmen, sophomore, and transfer students.

2. Increase the number of tenure track appointments and balance the ratio of fulltime and part-time faculty. In order to set the stage for a long future of high quality academic programs, at both the undergraduate and graduate levels, as well as scholarly productivity and national recognition, USFSP will recruit additional full-time faculty in key disciplines. This will facilitate the continued enhancement of the student experience through increased opportunities for faculty mentorship of undergraduate and graduate student research, increased engagement of faculty with the students; and increased student retention and degree completion. 
3. Develop and implement a focused initiative for greater student retention and graduation. This will be a coordinated, university-wide effort involving numerous constituencies and organizational units, including academic advising, tutoring services, wellness and counseling, admissions, residential life and education, student life and engagement, the library, and all academic units.

In 2013-2014, the institution participated in a major retention study conducted by the leading national authorities in the area, the firm of Scannell and Kurz. Their findings, which will be reported to the institution's leadership team in June, will inform ongoing changes and strategies to institutionalize retention, progression and graduation rates as institution-wide priorities. Initiatives to address retention and graduation have already been implemented: repurposing resources to create a student success center located in the heart of the campus; four-week academic progress checks with follow up by advising; increased academic tutoring; analyses of schedules and course offerings to facilitate progression. By 2015-2016, USFSP expects to increase freshman retention to 65 percent, 6-year graduation rates to 47 percent and decrease average time-to-degree to 5 years. 


\section{PERFORMANCE FUNDING METRICS}

Each universitv is reauired to comblete the table below. providing their goals for the metrics used in the

Performance Based Funding model that the Board of Governors approved at its January 2014 meeting. The Board of Governors will consider the shaded 2014-15 goals for approval.

\begin{tabular}{|c|c|c|c|c|c|c|}
\hline & $\begin{array}{l}\text { ONE-YEAR } \\
\text { TREND }\end{array}$ & $\begin{array}{l}2012-13 \\
\text { ACTUAL }\end{array}$ & $\begin{array}{c}2013-14 \\
\text { ESTIMATES }\end{array}$ & $\begin{array}{l}2014-15 \\
\text { GOALS }\end{array}$ & $\begin{array}{l}2015-16 \\
\text { GOALS }\end{array}$ & $\begin{array}{l}2016-17 \\
\text { GOALS }\end{array}$ \\
\hline \multicolumn{7}{|l|}{ Metrics Common To All Universities } \\
\hline $\begin{array}{l}\text { Percent of Bachelor's Graduates } \\
\text { Employed Full-time in Florida or } \\
\text { Continuing their Education in the U.S. } \\
\text { One Year After Graduation }\end{array}$ & $4 \% \Delta$ & $72 \%$ & $73 \%$ & $74 \%$ & $75 \%$ & $76 \%$ \\
\hline $\begin{array}{l}\text { Median Wages of Bachelor's Graduates } \\
\text { Employed Full-time in Florida } \\
\text { One-Year After Graduation }\end{array}$ & $6 \% \Delta$ & $\$ 34,800$ & $\$ 35,148$ & $\$ 35,500$ & $\$ 35,855$ & $\$ 36,214$ \\
\hline $\begin{array}{l}\text { Average Cost per Bachelor's Degree } \\
\text { [Instructional Costs to the University] }\end{array}$ & \multicolumn{6}{|c|}{ Reported at the USF System Level } \\
\hline $\begin{array}{l}\text { FTIC } 6 \text { year Graduation Rate } \\
\text { [lncludes full- and part-time students] }\end{array}$ & $8 \% \Delta$ & $40 \%$ & $44 \%$ & $45 \%$ & $46 \%$ & $47 \%$ \\
\hline $\begin{array}{l}\text { Academic Progress Rate } \\
\text { [FTIC } 2 \text { y ear Retention Rate with GPA>2 ] }\end{array}$ & $-3 \% \Delta$ & $74 \%$ & $75 \%$ & $76 \%$ & $77 \%$ & $78 \%$ \\
\hline $\begin{array}{l}\text { University Access Rate } \\
\text { [Percent of Fall Undergraduates with a Pell grant] }\end{array}$ & $2 \% \Delta$ & $39 \%$ & $39 \%$ & $39 \%$ & $39 \%$ & $39 \%$ \\
\hline $\begin{array}{l}\text { Bachelor's Degrees Awarded Within } \\
\text { Programs of Strategic Emphasis } \\
\text { [Based on list approved by BOG at 11/2013 meeting] }\end{array}$ & $-2 \% \Delta$ & $37 \%$ & $40 \%$ & $44 \%$ & $47 \%$ & $49 \%$ \\
\hline $\begin{array}{l}\text { Graduate Degrees Awarded Within } \\
\text { Programs of Strategic Emphasis } \\
\text { [Based on list approved by BOG at 11/2013 meeting] }\end{array}$ & $1 \% \Delta$ & $31 \%$ & $31 \%$ & $33 \%$ & $38 \%$ & $44 \%$ \\
\hline \multicolumn{7}{|l|}{ Board of Governors Choice Metric } \\
\hline $\begin{array}{l}\text { Percent of Bachelor's Degrees } \\
\text { Without Excess Hours }\end{array}$ & $\mathrm{n} / \mathrm{a}$ & $59 \%$ & $62 \%$ & $63 \%$ & $64 \%$ & $65 \%$ \\
\hline \multicolumn{7}{|l|}{ Board of Trustees Choice Metric } \\
\hline Postdoctoral Students & $0 \% \Delta$ & 0 & 0 & 0 & 0 & 0 \\
\hline
\end{tabular}

Note: Metrics are defined in appendix. 


\section{KEY PERFORMANCE INDICATORS}

The Board of Governors has selected the following Key Performance Indicators from its 2012-2025 System Strategic Plan and from accountability metrics identified by the Florida Legislature. The Key Performance Indicators emphasize three primary areas of focus: Academic Quality, Operational Efficiency, and Return on Investment. The indicators address common goals across all universities while also providing flexibility to address institution-specific goals from a list of metrics in the 2012-2025 System Strategic Plan.

The Goals Specific to Research Universities apply only to those universities classified by the Carnegie Foundation for the Advancement of Teaching as being a 'Research University'1, which includes Florida A\&M University (by university request), Florida Atlantic University, Florida International University, Florida State University, University of Central Florida, University of Florida, and the University of South Florida. 


\section{KEY PERFORMANCE INDICATORS}

The Board of Governors will consider the shaded 2014-15 goals for approval.

\section{Goals Common to All Universities}

\section{Academic Quality}

\section{National Ranking for University and Programs}

At the institutional level, USFSP continues to be ranked in the top 50 among regional public universities in the South by US News and World Reports. The USFSP College of Business is accredited by AACSB in both business and accounting, a double honor held by $1 \%$ of colleges of business globally. In 2014, USFSP's MBA program was ranked in the top 100 on-line programs in the US and $4^{\text {th }}$ in FL by US News and World Reports. USFSP also offers its students memberships in 10 national honor societies and continues to seek membership at both the disciplinary and institutional levels.

\begin{tabular}{|c|c|c|c|c|c|c|}
\hline & $\begin{array}{l}\text { TREND } \\
\text { (2008-09 to } \\
2012-13) \\
\end{array}$ & $\begin{array}{l}2012-13 \\
\text { ACTUAL } \\
\end{array}$ & $\begin{array}{c}\text { 2013-14 } \\
\text { ESTIMATES } \\
\end{array}$ & $\begin{array}{l}2014-15 \\
\text { GOALS }\end{array}$ & $\begin{array}{l}\text { 2015-16 } \\
\text { GOALS }\end{array}$ & $\begin{array}{l}2016-17 \\
\text { GOALS }\end{array}$ \\
\hline SAT Score [for 3 subtests] & $-3 \% \Delta$ & 1585 & 1636 & 1640 & 1642 & 1644 \\
\hline High School GPA & $2 \% \Delta$ & 3.57 & 3.78 & 3.79 & 3.8 & 3.81 \\
\hline $\begin{array}{l}\text { Professional/Licensure Exam } \\
\text { First-time Pass Rates }{ }^{1} \\
\text { Exams Above Benchmarks } \\
\text { Exams Below Benchmarks }\end{array}$ & $\begin{array}{l}\mathrm{n} / \mathrm{a} \\
\mathrm{n} / \mathrm{a}\end{array}$ & \multicolumn{5}{|c|}{ Reported at the USF System Level } \\
\hline \multicolumn{7}{|l|}{ Operational Efficiency } \\
\hline Freshman Retention Rate & $-8 \% \Delta$ & $60 \%$ & $61 \%$ & $63 \%$ & $64 \%$ & $65 \%$ \\
\hline $\begin{array}{l}\text { FTIC Graduation Rates } \\
\text { In } 4 \text { years (or less) } \\
\text { In } 6 \text { years (or less) }\end{array}$ & $\begin{array}{l}12 \% \Delta \\
8 \% \Delta\end{array}$ & $\begin{array}{l}23 \% \\
40 \%\end{array}$ & $\begin{array}{l}25 \% \\
44 \%\end{array}$ & $\begin{array}{l}26 \% \\
45 \%\end{array}$ & $\begin{array}{l}26 \% \\
46 \%\end{array}$ & $\begin{array}{l}27 \% \\
47 \%\end{array}$ \\
\hline $\begin{array}{l}\text { AA Transfer Graduation Rates } \\
\text { In } 2 \text { years (or less) } \\
\text { In } 4 \text { years (or less) }\end{array}$ & $\begin{array}{l}-3 \% \Delta \\
1 \% \Delta\end{array}$ & $\begin{array}{l}22 \% \\
58 \%\end{array}$ & $\begin{array}{l}24 \% \\
60 \%\end{array}$ & $\begin{array}{l}25 \% \\
61 \%\end{array}$ & $\begin{array}{l}26 \% \\
62 \%\end{array}$ & $\begin{array}{l}28 \% \\
63 \%\end{array}$ \\
\hline $\begin{array}{l}\text { Average Time to Degree } \\
\text { (for FTIC) }\end{array}$ & $13 \% \Delta$ & $5.2 \mathrm{yrs}$ & $5.2 \mathrm{yrs}$ & $5.1 \mathrm{yrs}$ & $5.1 \mathrm{yrs}$ & $5 \mathrm{yrs}$ \\
\hline \multicolumn{7}{|l|}{ Return on Investment } \\
\hline Bachelor's Degrees Awarded & $23 \% \Delta$ & 826 & 857 & 882 & 908 & 935 \\
\hline $\begin{array}{l}\text { Percent of Bachelor's Degrees } \\
\text { in STEM }\end{array}$ & $3 \% \Delta$ & $8 \%$ & $10 \%$ & $15 \%$ & $18 \%$ & $20 \%$ \\
\hline Graduate Degrees Awarded & $-9 \% \Delta$ & 143 & 176 & 181 & 186 & 192 \\
\hline $\begin{array}{l}\text { Percent of Graduate Degrees } \\
\text { in STEM }\end{array}$ & $5 \% \Delta$ & $6 \%$ & $8 \%$ & $8 \%$ & $9 \%$ & $9 \%$ \\
\hline
\end{tabular}

Notes: (1) Professional licensure pass rates are based on the 2012-13 Annual Accountability Report with data that spans multiple time periods, (2) The methodology for calculating the percent of undergraduate seniors participating in a research course will be determined during the 2014 summer. 


\section{KEY PERFORMANCE INDICATORS}

\section{Institution Specific Goals}

Each university will provide updates for the metric qoals reported in last year's Work Plans. The Board of Governors will consider the shaded 2014-15 goals for approval. University leadership will need to discuss any proposed changes with Board of Governors staff.

\begin{tabular}{lcccccc} 
& $\begin{array}{c}\text { TREND } \\
(2008-09 \text { to } \\
\text { 2012-13) }\end{array}$ & $\begin{array}{c}\text { 2012-13 } \\
\text { ACTUAL }\end{array}$ & $\begin{array}{c}\text { 2013-14 } \\
\text { ESTIMATES }\end{array}$ & $\begin{array}{c}\text { 2014-15 } \\
\text { GOALS }\end{array}$ & $\begin{array}{c}\text { 2015-16 } \\
\text { GOALS }\end{array}$ & $\begin{array}{c}\text { 2016-17 } \\
\text { GOALS }\end{array}$ \\
\hline $\begin{array}{l}\text { Bachelor's Degrees in Areas of } \\
\text { Strategic Emphasis }\end{array}$ & $15 \% \Delta$ & 304 & 324 & 360 & 370 & 390 \\
\hline $\begin{array}{l}\text { Percent of Course Sections Offered } \\
\text { via Distance and Blended Learning* }\end{array}$ & Not avail. & $18 \%$ & $18 \%$ & $22 \%$ & $25 \%$ & $26 \%$ \\
\hline $\begin{array}{l}\text { Maintain Carnegie Community } \\
\text { Engagement Classification }\end{array}$ & $100 \%{ }^{*}$ & $\mathrm{xx}$ & $\mathrm{xx}$ & $\mathrm{xX}$ & $\mathrm{xx}$ & $\mathrm{xX}$ \\
\hline
\end{tabular}

*Data populated by USFSP.

To further distinguish the university's distinctive mission, the university may choose to provide two additional narrative and metric goals that are based on the university's own strategic plan.

Goal 1. Improve baccalaureate retention and graduation (USF System Goal 1); USFSP will focus on improving student outcomes in key mathematics courses through continued implementation of its Quality Enhancement Plan; focus on improving access to academic support (i.e., tutoring); continued emphasis on strengthening academic advising; and university-wide interventions for increasing student success.

Metric: Increase 6-year FTIC baccalaureate graduation rate.

$\begin{array}{llllll}8 \% \Delta & 40 \% & 44 \% & 45 \% & 46 \% & 47 \%\end{array}$

*USFSP earned this designation in 2011-12 and will retain this designation through 2015, the next application cycle. 


\section{FISCAL INFORMATION}

University Revenues (in Millions of Dollars)

\begin{tabular}{lcc} 
& $\begin{array}{c}2013-14 \\
\text { Actual }\end{array}$ & $\begin{array}{c}2014-15 \\
\text { Appropriations }\end{array}$ \\
\hline Education \& General - Main Operations & & $\$ 24.3$ \\
\hline State Funds & $\$ 22.3$ & $\$ 26.2$ \\
\hline Tuition & $\$ 25.9$ & $\$ 50.5$ \\
\hline TOTAL MAIN OPERATIONS & $\$ 48.2$ & \\
\hline Education \& General - Health-Science Center / Medical Schools & & \\
\hline State Funds & & \\
\hline Tuition & & $\$ 0.0$ \\
\hline TOTAL HSC & $\$ 0.0$ & $\$ 50.5$ \\
\hline$\quad$ EDUCATION \& GENERAL TOTAL REVENUES & $\$ 48.2$ & \\
\hline
\end{tabular}

Note: State funds include General Revenue funds, Lottery funds, Federal Stimulus funds, and Phosphate Research funds (for Polytechnic) appropriated by the Florida Legislature (as reported in the Annual Accountability Report). Actual tuition inclu des base tuition and tuition differential fee revenues for residentand non-residentundergraduate and graduate students net of waivers (as reported in the Annual Accountability Report). Actual tuition revenues are notyetavailable for the 2013-14 year.

\section{OTHER BUDGET ENTITIES}

\section{Auxiliary Enterprises}

Resources associated with auxiliary units that are self supporting through fees, payments and charges. Examples include housing, food services, bookstores, parking services, health centers.

Revenues $\$ 13.0 \quad \mathrm{n} / \mathrm{a}$

\section{Contracts \& Grants}

Resources received fromfederal, state or private sources for the purposes of conducting research and public service activities.

Revenues $\quad \$ 3.7 \quad \mathrm{n} / \mathrm{a}$

\section{Local Funds}

Resources associated with student activity (supported by the student activity fee), student financial aid, concessions, inter collegiate athletics, technology fee, green fee, and student life \& servicesfee.
Revenues
$\$ 4.4$
n/a

\section{Faculty Practice Plans}

Revenues/receipts are funds generated fromfaculty practice plan activities.

Revenues

n/a

OTHER BUDGET ENTITY TOTAL REVENUES

UNIVERSITY REVENUES GRANDTOTAL
$\$ 21.1$

$\$ 69.3$ n/a

n/a 


\section{FISCAL INFORMATION (continued)}

\section{Undergraduate Resident Tuition Summary (for 30 credit hours)}

\begin{tabular}{lccccc} 
& $\begin{array}{c}\text { FY 2012-13 } \\
\text { ACTUAL }\end{array}$ & $\begin{array}{c}\text { FY 2013-14 } \\
\text { ACTUAL }\end{array}$ & $\begin{array}{c}\text { FY 2014-15 } \\
\text { REQUEST }\end{array}$ & $\begin{array}{c}\text { FY 2015-16 } \\
\text { PLANNED }\end{array}$ & $\begin{array}{c}\text { FY 2016-17 } \\
\text { PLANNED }\end{array}$ \\
\hline Base Tuition & $\$ 3,100$ & $\$ 3,152$ & $\$ 3,152$ & $\$ 3,152$ & $\$ 3,152$ \\
\hline Tuition Differential Fee & $\$ 1,054$ & $\$ 1,054$ & $\$ 1,054$ & $\$ 1,054$ & $\$ 1,054$ \\
\hline Percent Increase & $11 \%$ & $1,7 \%$ & $0 \%$ & $0 \%$ & $0 \%$ \\
\hline Required Fees $^{1}$ & $\$ 1,562$ & $\$ 1,615$ & $\$ 1,615$ & $\$ 1,615$ & $\$ 1,615$ \\
\hline TOTAL TUITION AND FEES & $\$ 5,716$ & $\$ 5,821$ & $\$ 5,821$ & $\$ 5,821$ & $\$ 5,821$
\end{tabular}

Note $^{1}$ : For more information regarding required fees see list of per credit hour fees and block fees on page 16.

\section{Student Debt Summary}

\begin{tabular}{|c|c|c|c|c|c|}
\hline J & $\begin{array}{r}2009-10 \\
\text { ACTUAL }\end{array}$ & $\begin{array}{r}2010-11 \\
\text { ACTUAL }\end{array}$ & $\begin{array}{r}2011-12 \\
\text { ACTUAL } \\
\end{array}$ & $\begin{array}{r}2012-13 \\
\text { ACTUAL } \\
\end{array}$ & $\begin{array}{c}2014-15 \\
\text { GOAL }\end{array}$ \\
\hline Percent of Bachelor's Recipients with Debt & $40 \%$ & $48 \%$ & $48 \%$ & $55 \%$ & $55 \%$ \\
\hline $\begin{array}{l}\text { Average Amount of Debt } \\
\text { for Bachelor's who have graduated with debt }\end{array}$ & $\$ 20,827$ & $\$ 22,836$ & $\$ 24,096$ & $\$ 19,858$ & $\$ 20,000$ \\
\hline NSLDS Cohort Year & 2008 & 2009 & 2010 & 2011 & $\begin{array}{l}2012 \\
\text { GOAL }\end{array}$ \\
\hline Student Loan Cohort Default Rate (3rd Year) & $10.1 \%$ & $9.8 \%$ & $7.5 \%$ draft & $\mathrm{n} / \mathrm{a}$ & $\mathrm{xx} \%$ \\
\hline
\end{tabular}

Cost of Attendance (for Full-Time Undergraduate Florida Residents in the Fall and Spring of 2013-14)

\begin{tabular}{ccccccc} 
& $\begin{array}{c}\text { TUITION } \\
\& \text { FEES }\end{array}$ & $\begin{array}{c}\text { BOOKS } \& \\
\text { SUPPLIES }\end{array}$ & $\begin{array}{c}\text { ROOM } \\
\& \text { BOARD }\end{array}$ & TRANSPORTATION & $\begin{array}{c}\text { OTHER } \\
\text { EXPENSES }\end{array}$ & TOTAL \\
\hline ON-CAMPUS & $\$ 5,820$ & $\$ 1,000$ & $\$ 9,250$ & $\$ 1,600$ & $\$ 2,500$ & $\$ 20,170$ \\
\hline AT HOME & $\$ 5,820$ & $\$ 1,000$ & $\$ 4,620$ & $\$ 1,600$ & $\$ 2,500$ & $\$ 15,540$ \\
\hline
\end{tabular}

Estimated Net Cost by Family Income (for Full-Time Undergraduate Florida Residents in the Fall and Spring of 2013-14)

\begin{tabular}{|c|c|c|c|c|c|c|}
\hline \multirow{2}{*}{$\begin{array}{l}\text { FAMILY } \\
\text { INCOME } \\
\text { GROUPS }\end{array}$} & \multicolumn{2}{|c|}{$\begin{array}{l}\text { FULL-TIME RESIDENT } \\
\text { UNDERGRADUATES }\end{array}$} & \multirow{2}{*}{$\begin{array}{c}\text { AVG. NET } \\
\text { COST OF } \\
\text { ATTENDANCE }\end{array}$} & \multirow{2}{*}{$\begin{array}{l}\text { AVG. NET } \\
\text { TUITION } \\
\text { \& FEES } \\
\end{array}$} & \multirow{2}{*}{$\begin{array}{l}\text { AVERAGE } \\
\text { GIFT AID } \\
\text { AMOUNT }\end{array}$} & \multirow{2}{*}{$\begin{array}{l}\text { AVERAGE } \\
\text { LOAN } \\
\text { AMOUNT }\end{array}$} \\
\hline & HEADCOUNT & PERCENT & & & & \\
\hline Below $\$ 40,000$ & 717 & $37 \%$ & $\$ 11,563$ & $-\$ 2,378$ & $\$ 7,682$ & $\$ 4,446$ \\
\hline$\$ 40,000-\$ 59,999$ & 253 & $13 \%$ & $\$ 13,563$ & $\$ 48$ & $\$ 5,250$ & $\$ 3,225$ \\
\hline$\$ 60,000-\$ 79,999$ & 190 & $10 \%$ & $\$ 15,299$ & $\$ 2,118$ & $\$ 3,257$ & $\$ 4,574$ \\
\hline$\$ 80,000-\$ 99,999$ & 146 & $8 \%$ & $\$ 16,660$ & $\$ 3,164$ & $\$ 2,108$ & $\$ 4,650$ \\
\hline$\$ 100,000$ Above & 429 & $22 \%$ & $\$ 16,911$ & $\$ 3,369$ & $\$ 1,984$ & $\$ 3,888$ \\
\hline Missing* & 202 & $10 \%$ & $\mathrm{n} / \mathrm{a}$ & $\$ 4,870$ & $\$ 417$ & $\$ 154$ \\
\hline TOTAL & 1,937 & $100 \%$ & $\$ 14,614^{*}$ & $\$ 826$ & $\$ 4,491$ & $\$ 3,743$ \\
\hline
\end{tabular}

Notes: This data only represents Fall and Spring financial aid data and is accurate as of March 31, 2014. Please note that small changes to Spring 2013 aw ards are possible before the data is finalized. Family Income Groups are based on the Total Family Income (including untaxed income) as reported on student FAFSA records. Full-time Students is a headcount based on at least 24 credit hours during Fall and Spring terms. Average Gift Aid includes all grants and scholarships from Federal, State, Univ ersity and other priv ate sources administered by the Financial Aid Office. Student waiv ers are also included in the Gift Aid amount. Gift Aid does not include the parental contribution tow ards EFC. Net Cost of Attendance is the actual av erage of the total Costs of Attendance (which will vary by income group due to the div ersity of students living on- \& off- campus) minus the av erage Gift Aid amount. Net Tuition \& Fees is the actual av erage of the total costs of tuition and fees (which will vary by income group due to the amount of credit hours students are enrolled) minus the av erage Gift Aid amount (see page 16 for list of fees that are included). Average Loan Am ount includes Federal (Perkins, Stafford, Ford Direct, and PLUS loans) and all priv ate loans. The bottom-line Average represents the av erage of all full-time undergraduate Florida residents (note*: the total Net Cost of Attendance does not include students with missing family income data). 'Missing' includes students who did not file a FAFSA. 


\section{FISCAL INFORMATION (continued) \\ TUITION DIFFERENTIAL FEE INCREASE REQUEST FOR FALL 2014}

\begin{tabular}{|c|c|}
\hline \multicolumn{2}{|c|}{ Effective Date } \\
\hline University Board of Trustees approval date: & June 3, 2014 \\
\hline \multicolumn{2}{|c|}{ Campus or Center Location } \\
\hline $\begin{array}{l}\text { Campus or center location to which the tuition differential fee } \\
\text { increase will apply (If the entire university, indicate as such): }\end{array}$ & Entire University \\
\hline \multicolumn{2}{|c|}{ Undergraduate Course(s) } \\
\hline $\begin{array}{l}\text { Course(s). (If the tuition differential fee applies to all university } \\
\text { undergraduate courses, indicate as such. If not, provide } \\
\text { rationale for the differentiation among courses): }\end{array}$ & All undergraduate courses \\
\hline \multicolumn{2}{|c|}{ Current and Proposed Increase in the Tuition Differential Fee } \\
\hline Current Undergraduate Tuition Differential per credit hour: & $\$ 35.14$ \\
\hline $\begin{array}{l}\text { Percentage tuition differential fee increase (calculated as a } \\
\text { percentage of the sum of base tuition plus tuition differential): }\end{array}$ & $0 \%$ \\
\hline \$ Increase in tuition differential per credit hour: & $\$ 0$ \\
\hline \$ Increase in tuition differential for 30 credit hours: & $\$ 0$ \\
\hline \multicolumn{2}{|c|}{ Projected Differential Revenue Generated } \\
\hline Incremental revenue generated in 2014-15 (projected): & $\$ 0$ \\
\hline Total differential fee revenue generated in 2014-15 (projected): & $\$ 3,338,300$ \\
\hline \multicolumn{2}{|c|}{ Intended Uses } \\
\hline \multicolumn{2}{|c|}{$\begin{array}{l}\text { Describe how the revenue will be used. } \\
\text { Cost-efficient utilization of instructional technology and innovation, along with investments in faculty and professional staff to } \\
\text { enhance timely college completion rates, attainment and career placement through activities such as: } \\
\text { - Need-Based Financial Aid (at 40\%): Expand access for students; and accelerated path to graduation. Provide much } \\
\text { needed financial support for talented students with limited income. } \\
\text { - Expanding the High Skilled Workforce and Supporting Job Placement: Expanded degree production in Areas of } \\
\text { Strategic Emphasis; Strengthened relationships with business and industry; Increased number of internships; } \\
\text { Expanded professional support for job placement through USFSP's Career Center. } \\
\text { - Academic Advising: Enhanced academic advising through technology and additional professional staff, focus on } \\
\text { goal setting, time-to-degree, improved graduation rates, reducing excess hours. Improved tracking of students and } \\
\text { graduates. }\end{array}$} \\
\hline \multicolumn{2}{|c|}{ Describe the Impact to the Institution if Tuition Differential is Not Approved } \\
\hline $\begin{array}{l}\text { Request to Modify or Wai } \\
\text { (pursuant to Section } 1001.706(3)(g) \text { the Board may consi } \\
\text { intended uses criteria identified in Regulation } 7.001(14 \\
\text { modification, purpose of the modificat }\end{array}$ & $\begin{array}{l}\text { Tuition Differential Uses } \\
\text { r waiving its regulations associated with the } 70 \% \text { / } 30 \% \\
\text { If the university requests a modification; identify the } \\
\text {, and rationale for the modification.) }\end{array}$ \\
\hline
\end{tabular}

FISCAL INFORMATION (continued) 


\section{TUITION DIFFERENTIAL SUPPLEMENTAL INFORMATION}

Provide the following information for the 2013-14 academic year.

\section{3-2014 - 70\% Inifiatives (list the initiatives provided in \\ University Update on Each Initiative}

the 2012-13 tuition differential request)

Improve graduation rates through QEP implementation

\begin{tabular}{l|} 
Increase faculty/student research and creative activity \\
\hline Enhanced undergraduate programs \\
Improve graduation rates through QEP implementation and \\
creation of Student Success Center
\end{tabular}

Two key faculty assigned duties to support QEP; revised

implementation plan to enhance student success; enhanced

tutoring; increase in FTIC graduation rate

Research funding at all-time high. Increased student presentations, research posters and papers and student research awards, teaching and research assistants. National student research awards. E \& G funds reallocated to support these efforts because of tuition differential support in other areas.

Senior faculty reassigned to teach in Gen Ed

Two key faculty assigned duties to support QEP; revised

implementation plan to enhance student success; enhanced

tutoring; increase in FTIC graduation rate; Student Success

Center, expansion of Tutoring Center

\section{Additional Detail, where applicable:}

Total Number of Faculty Hired or Retained (funded by tuition 26

differential):

\begin{tabular}{|l|l|}
\hline Total Number of Advisors Hired or Retained (funded by & 3
\end{tabular}

tuition differential):

Total Number of Course Sections Added or Saved (funded

by tuition differential):

130

130

6

(20)

2013-2014 - 30\% Inifiatives (list the initiatives provided in

the 2013-14 tuition differential request)

Expand access for students and accelerated path to graduation

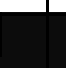

\section{University Update on Each Initiative}

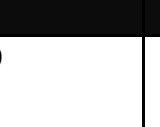

Two senior students were incentivized to graduate in four years with a $\$ 2,500$ grant which will repay $\$ 2,500$ in student loans if the student graduated in spring 2013. Awards will be made once degree verification can be confirmed.

\begin{tabular}{l}
\hline Provide financial support for students with limited income \\
\hline $\begin{array}{l}\text { More students supported with financial aid scholarships and } \\
\text { reduced loan indebtedness }\end{array}$ \\
\hline Expand access for swd
\end{tabular}
Expand access for students and accelerated path to graduation

Larger USF need based grant awards were made to students
based on their academic potential and USF academic record.

The number of students receiving a need based grant increased from 509 to 809 , or by $59 \%$.

Two senior students were incentivized to graduate in four years with a $\$ 2,500$ grant which will repay $\$ 2,500$ in student loans if the student graduated in spring 2013. Awards will be made once degree verification can be confirmed.

\section{Additional Information (estimates as of April 30, 2014):}

Unduplicated Count of Students Receiving at least one

Tuition Differential-Funded Award:

$\$$ Mean (per student receiving an award) of Tuition

Differential-Funded Awards:

\$ Minimum (per student receiving an award) of Tuition

Differential-Funded Awards:

\$ Maximum (per student receiving an award) of Tuition

Differential-Funded Awards: 
TUITION DIFFERENTIAL COLLECTIONS, EXPENDITURES, \& AVAILABLE BALANCES - FISCAL YEAR 2013-14 AND 2014-15

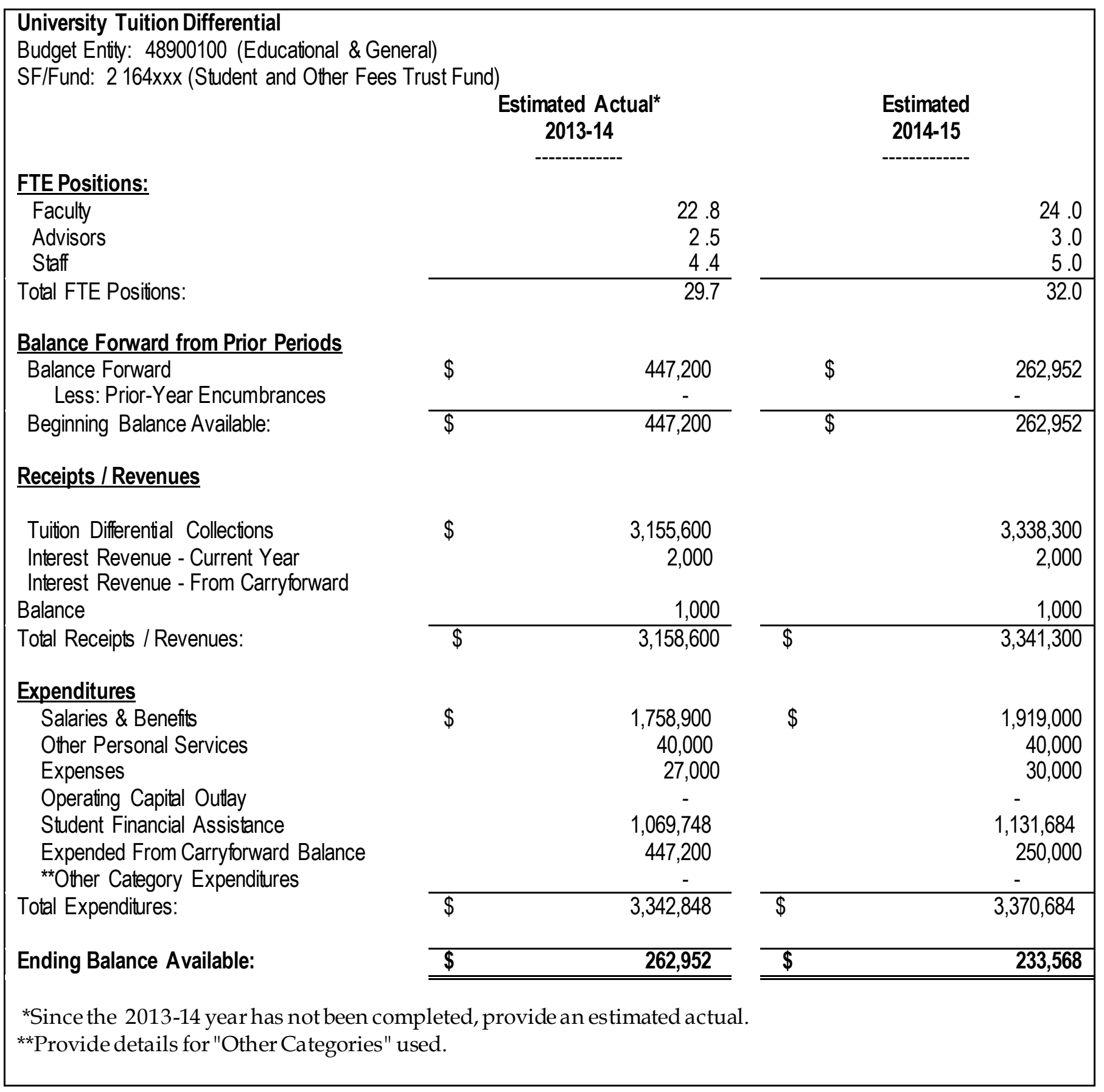




\section{FISCAL INFORMATION (continued) UNIVERSITY TUITION, FEES AND HOUSING PROJECTIONS}

University: University of South Florida, St. Petersburg

\begin{tabular}{|c|c|c|c|c|c|c|c|}
\hline \multirow{2}{*}{$\underline{\text { Undergraduate Students }}$} & \multicolumn{3}{|c|}{----------------Actual--------------- } & \multicolumn{4}{|c|}{ 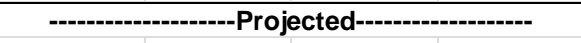 } \\
\hline & 2011-12 & 2012-13 & 2013-14 & 2014-15 & 2015-16 & 2016-17 & 2017-18 \\
\hline \multicolumn{8}{|l|}{ Tuition: } \\
\hline Base Tuition - (0\% inc. for $2014-15$ to $2017-18)$ & $\$ 103.32$ & $\$ 103.32$ & $\$ 105.07$ & $\$ 105.07$ & $\$ 105.07$ & $\$ 105.07$ & $\$ 105.07$ \\
\hline Tuition Differential & 21.42 & $\$ 35.14$ & $\$ 35.14$ & $\$ 35.14$ & $\$ 35.14$ & $\$ 35.14$ & $\$ 35.14$ \\
\hline Total Base Tuition \& Differential per Credit Hour & $\$ 124.74$ & $\$ 138.46$ & $\$ 140.21$ & $\$ 140.21$ & $\$ 140.21$ & $\$ 140.21$ & $\$ 140.21$ \\
\hline$\%$ Change & & $11.0 \%$ & $1.3 \%$ & $0.0 \%$ & $0.0 \%$ & $0.0 \%$ & $0.0 \%$ \\
\hline \multicolumn{8}{|l|}{ Fees (per credit hour): } \\
\hline Student Financial Aid ${ }^{1}$ & $\$ 5.16$ & $\$ 5.16$ & $\$ 5.25$ & $\$ 5.25$ & $\$ 5.25$ & $\$ 5.25$ & $\$ 5.25$ \\
\hline Capital Improvement $^{2}$ & $\$ 4.76$ & $\$ 6.76$ & $\$ 6.76$ & $\$ 6.76$ & $\$ 6.76$ & $\$ 6.76$ & $\$ 6.76$ \\
\hline Activity \& Service & $\$ 24.80$ & $\$ 25.05$ & $\$ 25.63$ & $\$ 25.63$ & $\$ 25.63$ & $\$ 25.63$ & $\$ 25.63$ \\
\hline Health & $\$ 2.64$ & $\$ 3.90$ & $\$ 4.90$ & $\$ 4.90$ & $\$ 4.90$ & $\$ 4.90$ & $\$ 4.90$ \\
\hline Athletic & $\$ 2.45$ & $\$ 2.45$ & $\$ 2.45$ & $\$ 2.45$ & $\$ 2.45$ & $\$ 2.45$ & $\$ 2.45$ \\
\hline Transportation Access & $\$ 2.25$ & $\$ 2.25$ & $\$ 2.25$ & $\$ 2.25$ & $\$ 2.25$ & $\$ 2.25$ & $\$ 2.25$ \\
\hline Technology ${ }^{1}$ & $\$ 5.16$ & $\$ 5.16$ & $\$ 5.25$ & $\$ 5.25$ & $\$ 5.25$ & $\$ 5.25$ & $\$ 5.25$ \\
\hline Green Fee (USF, NCF, UWF only) & $\$ 1.00$ & $\$ 1.00$ & $\$ 1.00$ & $\$ 1.00$ & $\$ 1.00$ & $\$ 1.00$ & $\$ 1.00$ \\
\hline \multicolumn{8}{|l|}{ Student Life \& Services Fee (UNF only) } \\
\hline Marshall Center Fee (USF only) & & & & & & & \\
\hline \multicolumn{8}{|l|}{ Student Affairs Facility Use Fee (FSU only) } \\
\hline Total Fees & $\$ 48.22$ & $\$ 51.73$ & $\$ 53.49$ & $\$ 53.49$ & $\$ 53.49$ & $\$ 53.49$ & $\$ 53.49$ \\
\hline Total Tuition and Fees per Credit Hour & $\$ 172.96$ & $\$ 190.19$ & $\$ 193.70$ & $\$ 193.70$ & $\$ 193.70$ & $\$ 193.70$ & $\$ 193.70$ \\
\hline$\%$ Change & & $10.0 \%$ & $1.8 \%$ & $0.0 \%$ & $0.0 \%$ & $0.0 \%$ & $0.0 \%$ \\
\hline \multicolumn{8}{|l|}{ Fees (block per term): } \\
\hline \multicolumn{8}{|l|}{ Activity \& Service } \\
\hline \multicolumn{8}{|l|}{ Health } \\
\hline Athletic & $\$ 5.00$ & $\$ 5.00$ & $\$ 5.00$ & $\$ 5.00$ & $\$ 5.00$ & $\$ 5.00$ & $\$ 5.00$ \\
\hline \multicolumn{8}{|l|}{ Transportation Access } \\
\hline \multicolumn{8}{|l|}{ Marshall Center Fee (USF only) } \\
\hline \multirow{2}{*}{\multicolumn{8}{|c|}{$\begin{array}{l}\text { Student Affairs Facility Use Fee (FSU only) } \\
\text { List any new fee proposed }\end{array}$}} \\
\hline \multicolumn{4}{|l|}{ List any new fee proposed } & & & & \\
\hline Total Block Fees per term & $\$ 5.00$ & $\$ 5.00$ & $\$ 5.00$ & $\$ 5.00$ & $\$ 5.00$ & $\$ 5.00$ & $\$ 5.00$ \\
\hline$\%$ Change & & $0.0 \%$ & $0.0 \%$ & $0.0 \%$ & $0.0 \%$ & $0.0 \%$ & $0.0 \%$ \\
\hline Total Tuition for $\mathbf{3 0}$ Credit Hours & $\$ 3,742.20$ & $\$ 4,153.80$ & $\$ 4,206.30$ & $\$ 4,206.30$ & $\$ 4,206.30$ & $\$ 4,206.30$ & $\$ 4,206.30$ \\
\hline Total Fees for 30 Credit Hours & $\$ 1,456.60$ & $\$ 1,561.90$ & $\$ 1,614.70$ & $\$ 1,614.70$ & $\$ 1,614.70$ & $\$ 1,614.70$ & $\$ 1,614.70$ \\
\hline Total Tuition and Fees for 30 Credit Hours & $\$ 5,198.80$ & $\$ 5,715.70$ & $\$ 5,821.00$ & $\$ 5,821.00$ & $\$ 5,821.00$ & $\$ 5,821.00$ & $\$ 5,821.00$ \\
\hline \$ Change & & $\$ 516.90$ & $\$ 105.30$ & $\$ 0.00$ & $\$ 0.00$ & $\$ 0.00$ & $\$ 0.00$ \\
\hline$\%$ Change & & $9.9 \%$ & $1.8 \%$ & $0.0 \%$ & $0.0 \%$ & $0.0 \%$ & $0.0 \%$ \\
\hline \multicolumn{8}{|l|}{ Out-of-State Fees } \\
\hline Out-of-State Undergraduate Fee & $\$ 291.68$ & $\$ 315.00$ & $\$ 346.50$ & $\$ 346.50$ & $\$ 346.50$ & $\$ 346.50$ & $\$ 346.50$ \\
\hline Out-of-State Undergraduate Student Financial Aid ${ }^{3}$ & $\$ 14.58$ & $\$ 15.75$ & $\$ 17.32$ & $\$ 17.32$ & $\$ 17.32$ & $\$ 17.32$ & $\$ 17.32$ \\
\hline Total per credit hour & $\$ 306.26$ & $\$ 330.75$ & $\$ 363.82$ & $\$ 363.82$ & $\$ 363.82$ & $\$ 363.82$ & $\$ 363.82$ \\
\hline$\%$ Change & & $8.0 \%$ & $10.0 \%$ & $0.0 \%$ & $0.0 \%$ & $0.0 \%$ & $0.0 \%$ \\
\hline Total Tuition for 30 Credit Hours & $\$ 12,492.60$ & $\$ 13,603.80$ & $\$ 14,601.30$ & $\$ 14,601.30$ & $\$ 14,601.30$ & $\$ 14,601.30$ & $\$ 14,601.30$ \\
\hline Total Fees for 30 Credit Hours & $\$ 1,894.00$ & $\$ 2,034.40$ & $\$ 2,134.30$ & $\$ 2,134.30$ & $\$ 2,134.30$ & $\$ 2,134.30$ & $\$ 2,134.30$ \\
\hline Total Tuition and Fees for 30 Credit Hours & $\$ 14,386.60$ & $\$ 15,638.20$ & $\$ 16,735.60$ & $\$ 16,735.60$ & $\$ 16,735.60$ & $\$ 16,735.60$ & $\$ 16,735.60$ \\
\hline \$ Change & & $\$ 1,251.60$ & $\$ 1,097.40$ & $\$ 0.00$ & $\$ 0.00$ & $\$ 0.00$ & $\$ 0.00$ \\
\hline$\%$ Change & & $8.7 \%$ & $7.0 \%$ & $0.0 \%$ & $0.0 \%$ & $0.0 \%$ & $0.0 \%$ \\
\hline
\end{tabular}




\section{ENROLLMENT PLANNING}

Planned Enrollment Growth by Student Type (for all E\&G students at all campuses)

\begin{tabular}{|c|c|c|c|c|c|c|c|c|c|}
\hline \multirow[b]{2}{*}{ UNDERGRADUATE } & $\begin{array}{l}5 \text { YEAR } \\
\text { TREND } \\
(2008-13)\end{array}$ & \multicolumn{2}{|c|}{$\begin{array}{c}\text { Fall } 2013 \\
\text { ACTUAL } \\
\text { HEADCOUNT }\end{array}$} & \multicolumn{2}{|c|}{$\begin{array}{c}\text { Fall } 2014 \\
\text { PLANNED } \\
\text { HEADCOUNT }\end{array}$} & \multicolumn{2}{|c|}{$\begin{array}{c}\text { Fall } 2015 \\
\text { PLANNED } \\
\text { HEADCOUNT }\end{array}$} & \multicolumn{2}{|c|}{$\begin{array}{c}\text { Fall } 2016 \\
\text { PLANNED } \\
\text { HEADCOUNT }\end{array}$} \\
\hline & & & & & & & & & \\
\hline FTIC (Regular Admit) & $62 \% \Delta$ & 1,624 & $41 \%$ & 1,400 & $41 \%$ & 1,414 & $41 \%$ & 1,428 & $41 \%$ \\
\hline FTIC (Profile Admit) & $200 \% \Delta$ & 12 & $0 \%$ & 0 & $0 \%$ & 0 & $0 \%$ & 0 & $0 \%$ \\
\hline AA Transfers* & $15 \% \Delta$ & 1,486 & $38 \%$ & 1,298 & $38 \%$ & 1,311 & $38 \%$ & 1,324 & $38 \%$ \\
\hline Other Transfers & $-1 \% \Delta$ & 827 & $21 \%$ & 717 & $21 \%$ & 724 & $21 \%$ & 732 & $21 \%$ \\
\hline Subtotal & $26 \%$ & 3,949 & $100 \%$ & 3,415 & $100 \%$ & 3,449 & $100 \%$ & 3,484 & $100 \%$ \\
\hline \multicolumn{10}{|l|}{ GRADUATE STUDENTS } \\
\hline Master's & $23 \% \Delta$ & 552 & $100 \%$ & 568 & $100 \%$ & 615 & $100 \%$ & 633 & $100 \%$ \\
\hline Research Doctoral & $\% \Delta$ & $\mathrm{n} / \mathrm{a}$ & $x x \%$ & $\mathrm{n} / \mathrm{a}$ & $x x \%$ & $\mathrm{n} / \mathrm{a}$ & $x x \%$ & $\mathrm{n} / \mathrm{a}$ & $x x \%$ \\
\hline Professional Doctoral & $\% \Delta$ & $\mathrm{n} / \mathrm{a}$ & $x x \%$ & $\mathrm{n} / \mathrm{a}$ & $x x \%$ & $\mathrm{n} / \mathrm{a}$ & $x x \%$ & $\mathrm{n} / \mathrm{a}$ & $x x \%$ \\
\hline Subtotal & $23 \% \Delta$ & 552 & $100 \%$ & 568 & $100 \%$ & 615 & $100 \%$ & 633 & $100 \%$ \\
\hline NOT-DEGREE SEEKING & $26 \% \Delta$ & 239 & & 241 & & 244 & & 246 & \\
\hline MEDICAL & $\% \Delta$ & $n / a$ & & $n / a$ & & $n / a$ & & $n / a$ & \\
\hline TOTAL & $26 \% 4$ & 4,740 & & 4,224 & & 4,308 & & 4,363 & \\
\hline
\end{tabular}

Note*: AA transfers refer only to transfers from the Florida College System.

Planned Enrollment Growth by Method of Instruction (for all E\&G students at all campuses)

\begin{tabular}{|c|c|c|c|c|c|c|c|c|c|}
\hline & \multirow{2}{*}{$\begin{array}{c}2 \text { YEAR } \\
\text { TREND } \\
\text { (2010-11 to } \\
2012-13)\end{array}$} & \multicolumn{2}{|c|}{$2012-13$} & \multicolumn{2}{|c|}{ 2014-15 } & \multicolumn{2}{|c|}{$2015-16$} & \multicolumn{2}{|c|}{$2016-17$} \\
\hline & & $\begin{array}{l}\text { ACTUAL } \\
\text { FTE }\end{array}$ & $\begin{array}{l}\% \text { of } \\
\text { TOTAL }\end{array}$ & $\begin{array}{l}\text { PLANNED } \\
\text { FTE }\end{array}$ & $\begin{array}{c}\% \text { of } \\
\text { TOTAL }\end{array}$ & $\begin{array}{l}\text { PLANNED } \\
\text { FTE }\end{array}$ & $\begin{array}{c}\% \text { of } \\
\text { TOTAL }\end{array}$ & $\begin{array}{l}\text { PLANNED } \\
\text { FTE }\end{array}$ & $\begin{array}{c}\% \text { of } \\
\text { TOTAL }\end{array}$ \\
\hline \multicolumn{10}{|l|}{ UNDERGRADUATE } \\
\hline DISTANCE $(>80 \%)$ & $36 \% \Delta$ & 982 & $33 \%$ & 961 & $30 \%$ & 995 & $30 \%$ & 1,030 & $30 \%$ \\
\hline HYBRID (50\%-79\%) & $\% \Delta$ & 27 & $1 \%$ & 352 & $11 \%$ & 464 & $14 \%$ & 481 & $14 \%$ \\
\hline TRADITIONAL $(<50 \%)$ & $5 \% \Delta$ & 1982 & $66 \%$ & 1,891 & $59 \%$ & 1857 & $56 \%$ & 1,922 & $56 \%$ \\
\hline TOTAL & $15 \% \Delta$ & 2,991 & $100 \%$ & 3,204 & $100 \%$ & 3,317 & $100 \%$ & 3,433 & $100 \%$ \\
\hline \multicolumn{10}{|l|}{ GRADUATE } \\
\hline DISTANCE $(80 \%)$ & $82 \% \Delta$ & 113 & $39 \%$ & 80 & $26 \%$ & 83 & $26 \%$ & 85 & $26 \%$ \\
\hline HYBRID (50\%-79\%) & $-100 \% \Delta$ & 0 & $0 \%$ & 25 & $8 \%$ & 35 & $11 \%$ & 36 & $11 \%$ \\
\hline TRADITIONAL (<50\%) & $-12 \% \Delta$ & 173 & $61 \%$ & 202 & $66 \%$ & 200 & $63 \%$ & 207 & $63 \%$ \\
\hline TOTAL & $10 \% \Delta$ & 286 & $100 \%$ & 307 & $100 \%$ & 317 & $100 \%$ & 328 & $100 \%$ \\
\hline
\end{tabular}

Note: Full-time Equivalent(FTE) student is a measure of instructional effort (and student activity) that is based on the number of credit hours that students enroll. FTE is based on the Florida definition, which divides undergraduate credit hours by 40 and graduate credit hours by 32 . Distance Learning is a course in which at least 80 percent of the direct instruction of the course is deliv ered using some form of technology when the student and instructor are separated by time or space, or both (per 1009.24(17), F.S.). Hybrid is a course where $50 \%$ to $79 \%$ of the instruction is deliv ered using some form of technology, when the student and instructor are separated by time or space, or both (per SUDS data element 2052). Traditional (and Technology Enhanced) refers to primarily face to face instruction utilizing some form of technology for delivery of supplemental course materials for $n o$ more than $49 \%$ of instruction (per SUDS data element 2052). 
ENROLLMENT PLANNING (continued)

Planned Enrollment Plan by Residency and Student Level (Florida FTE)

\begin{tabular}{|c|c|c|c|c|c|c|c|}
\hline Estimated & Funded & Planned & Planned & Planned & Planned & Planned & Planned \\
\hline $\begin{array}{c}\text { Actual } \\
2013-14\end{array}$ & 2014-15 & 2014-15 & $2015-16$ & 2016-17 & 2017-18 & 2018-19 & 2019-20 \\
\hline
\end{tabular}

\begin{tabular}{|c|c|c|c|c|c|c|c|c|c|}
\hline \multicolumn{10}{|c|}{ STATEFUNDABLE } \\
\hline \multicolumn{10}{|c|}{ Florida Resident } \\
\hline LOWER & 858 & 657 & 700 & 710 & 725 & 754 & 784 & 815 & $3.20 \%$ \\
\hline UPPER & 1,486 & 1,486 & 1,462 & 1,470 & 1,475 & 1,534 & 1,595 & 1,659 & $2.69 \%$ \\
\hline GRAD I & 215 & 227 & 223 & 230 & 238 & 247 & 255 & 264 & $3.50 \%$ \\
\hline GRAD ॥ & n/a & n/a & $\mathrm{n} / \mathrm{a}$ & n/a & n/a & n/a & $\mathrm{n} / \mathrm{a}$ & n/a & $\mathrm{n} / \mathrm{a}$ \\
\hline TOTAL & 2,559 & 2370 & 2,385 & 2,410 & 2,438 & 2,535 & 2,634 & 2,738 & $3.00 \%$ \\
\hline \multicolumn{10}{|c|}{ Non-Resident } \\
\hline LOWER & 36 & 0 & 37 & 39 & 40 & 41 & 43 & 44 & $3.50 \%$ \\
\hline UPPER & 34 & 0 & 35 & 36 & 38 & 39 & 40 & 42 & $3.50 \%$ \\
\hline GRAD I & 15 & 0 & 16 & 16 & 17 & 17 & 18 & 18 & $3.50 \%$ \\
\hline GRAD ॥ & n/a & n/a & $\mathrm{n} / \mathrm{a}$ & n/a & n/a & n/a & $n / a$ & n/a & $\mathrm{n} / \mathrm{a}$ \\
\hline TOTAL & 85 & 0 & 88 & 91 & 94 & 98 & 101 & 104 & $3.50 \%$ \\
\hline \multicolumn{10}{|l|}{ TOTAL } \\
\hline LOWER & 894 & 657 & 737 & 749 & 765 & 795 & 827 & 859 & $3.40 \%$ \\
\hline UPPER & 1,520 & 1,486 & 1,497 & 1,506 & 1,513 & 1,573 & 1,635 & 1,701 & $2.80 \%$ \\
\hline GRAD I & 230 & 227 & 239 & 246 & 255 & 264 & 273 & 282 & $3.50 \%$ \\
\hline GRAD II & $\mathrm{n} / \mathrm{a}$ & $\mathrm{n} / \mathrm{a}$ & $\mathrm{n} / \mathrm{a}$ & $\mathrm{n} / \mathrm{a}$ & $\mathrm{n} / \mathrm{a}$ & $\mathrm{n} / \mathrm{a}$ & $\mathrm{n} / \mathrm{a}$ & $\mathrm{n} / \mathrm{a}$ & $\mathrm{n} / \mathrm{a}$ \\
\hline TOTAL & 2,644 & 2,370 & 2,473 & 2,501 & 2,533 & 2,632 & 2,735 & 2,842 & $3.00 \%$ \\
\hline \multicolumn{10}{|c|}{ NOT STATEFUNDABLE } \\
\hline LOWER & 360 & n/a & 373 & 386 & 399 & 413 & 428 & 443 & $3.50 \%$ \\
\hline UPPER & 647 & n/a & 670 & 693 & 717 & 742 & 768 & 795 & $3.50 \%$ \\
\hline GRAD I & 106 & n/a & 110 & 114 & 118 & 122 & 126 & 130 & $3.50 \%$ \\
\hline GRAD II & $\mathrm{n} / \mathrm{a}$ & n/a & $\mathrm{n} / \mathrm{a}$ & $\mathrm{n} / \mathrm{a}$ & n/a & $\mathrm{n} / \mathrm{a}$ & $\mathrm{n} / \mathrm{a}$ & $\mathrm{n} / \mathrm{a}$ & $3.50 \%$ \\
\hline TOTAL & 1,113 & $\mathrm{n} / \mathrm{a}$ & 1,152 & 1,192 & 1,234 & 1,277 & 1,322 & 1,368 & $3.50 \%$ \\
\hline
\end{tabular}

Note: Full-time Equivalent (FTE) student is a measure of instructional effort (and student activity) that is based on the number of credit hours that students enroll. FTE is based on the Florida definition, which divides undergraduate credit hours by 40 and graduate credit hours by 32 . Note*:The average annual growth rate is based on the annual growth rate from 2014-15 to 2019-20. 


\section{ACADEMIC PROGRAM COORDINATION}

\section{New Programs For Consideration by University in AY 2014-15}

The S.U.S. Council of Academic Vice Presidents (CAVP) Academic Program Coordination Work Group will review these programs as part of their on-going coordination efforts. The programs listed below are based on the 2013-14 Work Plan list for programs under consideration for 2014-16.

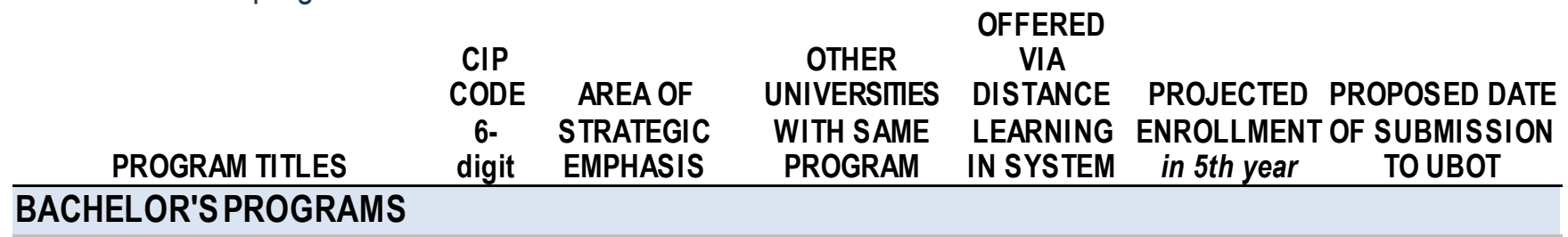

MASTER'S, SPECIALIST AND OTHER ADVANCED MASTER'S PROGRAMS

\begin{tabular}{|c|c|c|c|c|c|c|}
\hline Master of Accountancy & 52.0301 & $\begin{array}{l}\text { Critical Workforce } \\
\text { Gap Analysis }\end{array}$ & $\begin{array}{l}\text { UF, FSU, } \\
\text { FAU, FIU, } \\
\text { UCF, UNF }\end{array}$ & No & 45 & September 2014 \\
\hline
\end{tabular}

DOCTORAL PROGRAMS

New Programs For Consideration by University in 2015-17

These programs will be used in the 2015-16 Work Plan list for programs under consideration for 2015-16.

\begin{tabular}{|c|c|c|c|c|c|c|}
\hline PROGRAM TITLES & $\begin{array}{c}\text { CIP } \\
\text { CODE } \\
6 \text { 6-digit }\end{array}$ & $\begin{array}{c}\text { AREA OF STRATEGIC } \\
\text { EMPHASIS } \\
\end{array}$ & $\begin{array}{c}\text { OTHER } \\
\text { UNIVERSTES } \\
\text { WITH SAME } \\
\text { PROGRAM } \\
\end{array}$ & $\begin{array}{c}\text { OFFERED } \\
\text { VIA } \\
\text { DISTANCE } \\
\text { LEARNING } \\
\text { IN } \\
\text { SYSTEM } \\
\end{array}$ & $\begin{array}{l}\text { G PROJECTED } \\
\text { ENROLLMEN } \\
\text { in 5th year }\end{array}$ & $\begin{array}{c}\text { PROPOSED } \\
\text { DATE OF } \\
\text { VTSUBMISSION } \\
\text { TO UBOT } \\
\end{array}$ \\
\hline \multicolumn{7}{|c|}{ BACHELOR'S PROGRAMS } \\
\hline Data Analytics & 52.1301 & conomic Development--STEM & UF & & & March 2016 \\
\hline
\end{tabular}

\section{MASTER'S, SPECIALIST AND OTHER ADVANCED MASTER'S PROGRAMS}

\section{DOCTORAL PROGRAMS}




\section{DEFINITIONS}

\section{Performance Based Funding}

Percent of Bachelor's Graduates Employed Fulltime in Florida or Continuing their Education in the U.S. One Year After Graduation

\section{Median Wages of Bachelor's Graduates Employed Full-time in Florida One Year After Graduation}

\section{Average Cost per Bachelor's Degree} Instructional costs to the university

\section{Six Year FTIC} Graduation Rate
This metric is based on the percentage of a graduating class of bachelor's degree recipients who are employed full-ime in Florida or continuing their education somewhere in the United States. Students who do not have valid social security numbers are excluded. Note: Board staff have been in discussions with the Department of Economic Opportunity staff about the possibility of adding non-Florida employmentdata (from Wage Record Interchange System (WRIS2) to this metric for future evaluation.

Sources: State University Database System(SUDS), Florida Education \& Training Placement Information Program(FETPIP), National StudentClearinghouse.
This metric is based on annualized Unemployment Insurance (UI) wage data fromthe fourth fiscal quarter after graduation for bachelor's recipients. UI wage data does not include individuals who are self-employed, employed out of state, employed by the military or federal government, those without a valid social security number, or making less than minimum wage. Sources: State University Database System(SUDS), Florida Education \& Training Placement Information Program(FETPIP), National StudentClearinghouse.

For each of the last four years of data, the annual total undergraduate instructional expenditures were divided by the total fundable student credit hours to create a cost per credit hour for each year. This cost per credithour was then multiplied by 30 credit hours to derive an average annual cost. The average annual costfor each of the four years was summed to provide an average costper degree for a baccalaureate degree thatrequires 120 credithours. Sources: State University Database System(SUDS), Expenditure Analysis: ReportIV (2009-10 through 2012-13).

This metric is based on the percentage of first-ime-in-college (FTIC) students who started in the Fall (or summer continuing to Fall) term and had graduated fromthe same institution within six years. Students of degree programs longer than four years (eg, PharmD) areincluded in the cohorts. Students who are active duty military are not included in the data. Source: State University Database System(SUDS).

Academic

Progress Rate

2nd Year Retention

with GPA Above 2.0
This metric is based on the percentage of first-ime-in-college (FTIC) students who started in the Fall (or summer continuing to Fall) term and were enrolled full-time in their first semester and were still enrolled in the same institution during the Fall term following their first year with had a grade pointaverage (GPA) ofat least 2.0 at the end of their first year (Fall, Spring, Summer).

Source: State University Database System(SUDS).

This metric is based the number of undergraduates, enrolled during the fall term, who received a Pell-grantduring the fall term. Unclassified students, who are not eligible for Pell-grants, were excluded fromthis metric.

Source: State University Database System(SUDS).

This metric is based on the number of baccalaureate degrees awarded within the programs designated by the Board of Governors as 'Programs of Strategic Emphasis'. A student who has multiple majors in the subset of targeted Classification of Instruction Program codes will be counted twice (i.e., double-majors are included). Source: State University Database System(SUDS).

This metric is based on the number of graduate degrees awarded within the programs designated by the Board of Governors as 'Programs of Strategic Emphasis'. A student who has multiple majors in the subset of targeted Classification of Instruction Programcodes will be counted twice (i.e., double-majors are included). Source: State University Database System(SUDS). 
Freshmen in Top $10 \%$ of High School Class Applies to: NCF
Percent of all degree-seeking, first-time, first-year (freshman) students who had high school class rank within the top $10 \%$ of their graduating high school class.

Source: New College ofFlorida.

\section{BOG Choice Metrics}

\section{Percent of Bachelor's Degrees Without Excess Hours}

This metric is based on the percentage of baccalaureate degrees awarded within $110 \%$ of the credit hours required for a degree based on the Board of Governors Academic Program Inventory.

Note: It is important to note that the statutory provisions of the "Excess Hour Surcharge" (1009.286, FS) havebeen modified several times by the Florida Legislature, resulting in a phased-in approach thathas created three different cohorts of students with different requirements. The performance funding metric data is based on the latest statutory requirements that mandates $110 \%$ of required hours as the threshold. In accordance with statute, this metric excludes the following types of student credits (ie, accelerated mechanisms, remedial coursework, non-native credithours thatare not used toward the degree, non-native credit hours from failed, incomplete, withdrawn, or repeated courses, credithours from internship programs, credithours up to 10 foreign language credithours for transfer students in Florida, and credithours earned in military science courses that are part of the Reserve Officers' Training Corps (ROTC) program).

Source: State University Database System(SUDS).

This metric is based on the number of awards that faculty have earned in the arts, humanities, science, engineering and health fields as reported in the annual 'Top American Research Universities' report Twenty-three of the most prominentawards are considered, including: Getty Scholars in Residence, Guggenheim Fellows, Howard Hughes Medical Institute Investigators, MacArthur Foundation Fellows, National Endowmentfor the Humanities (NEH) Fellows, National Medal of Science and National Medal of Technology, RobertWood Johnson Policy Fellows, Sloan Research Fellows, Woodrow Wilson Fellows, to name a few awards. Source: Center for Measuring University Performance, Annual Reportof the Top American Research Universities (TARU).

This metric is based on the number of Top 50 university rankings that NCF earned fromthe following list of publications: US News and World Report, Forbes, Kiplinger, Washington Monthly, Center for Measuring University Performance, Times Higher Education World University Rankings, QS World University Ranking, and the Academic Ranking of World Universities.

Source: Board of Governors staff review.

\section{BOT Choice Metrics}

Percent of R\&D Expenditures Funded from External Sources FAMU

\section{Bachelor's Degrees Awarded to Minorities FAU, FGCU, FIU}

National Rank Higher than Predicted by the Financial Resources Ranking Based on U.S. and World News FSU
This metric reports the amount of research expenditures that was funded from federal, private industry and other (non-state and non-institutional) sources.

Source: National Science Foundation annual survey ofHigher Education Research and Development(HERD).

This metric is the number, or percentage, ofbaccalaureate degrees granted in an academic year to Non-Hispanic Black and Hispanic students. This metric does not include students classified as Non-ResidentAlien or students with a missing race code. Source: State University Database System(SUDS).

This metric is based on the difference between the Financial Resources rank and the overall University rank. U.S. News measures financial resources by using a two-year average spending per student on instruction, research, studentservices and related educational expenditures spending on sports, dorms and hospitals doesn't count. Source: US News and World Report's annual National University rankings. 


\section{Percent of Undergraduate Seniors Participating in a Research Course NCF}

This metric is based on the percentage of undergraduate seniors who participate in a research course during their senior year.

Source: New College ofFlorida.

\section{Number of Bachelor Degrees Awarded Annually UCF}

\section{Total Research Expenditures UF}

Percent of Course Sections
Offered via Distance and
Blended Learning
UNF

This metric is the number of baccalaureate degrees granted in an academic year. Students who earned two distinct degrees in the same academic year were counted twice; students who completed multiple majors or tracks were only counted once.

Source: State University Database System(SUDS).

This metric is the total expenditures (includes non-science \& engineering fields) for research \& developmentactivities within a given fiscal year.

Source: National Science Foundation annual survey ofHigher Education Research and Development(HERD).

This metric is based on the percentage of course sections classified as having atleast $50 \%$ of the instruction delivered using some form of technology, when the student and instructor are separated by time or space, or both.

Source: State University Database System(SUDS).

This metric is based on the number of post-doctoral appointees at the beginning of the academic year. A postdoctoral researcher has recently earned a doctoral (or foreign equivalent) degree and has a temporary paid appointment to focus on specialized research/scholarship under the supervision ofa senior scholar.

Source: National Science Foundation/National Institutes of Health annual Survey of Graduate Students and Postdoctorates in Science and Engineering (GSS).

\section{Percentage of Adult Undergraduates Enrolled UWF}

This metric is based on the percentage of undergraduates (enrolled during the fall term) who are at least 25 years old at the time of admission. This includes undergraduates who are not degree-seeking, or unclassified.

Source: State University Database System(SUDS).

\section{Preeminent Research University Funding Metrics}

Average GPA and SAT Score Public University National
Ranking

Freshman Retention Rate (Full-time, FTIC)

6-year Graduation Rate (Full-time, FTIC)
An average weighted grade pointaverage of 4.0 or higher and an average SAT score of 1800 or higher for fall semester incoming freshmen, as reported annually in the admissions data that universities submit to the Board of Governors. This data includes registered FTIC (student type='B','E') with an admission action of admitted or provisionally admitted ('A','P','X').

A top-50 ranking on at least two well-known and highly respected national public university rankings, reflecting national preeminence, using most recentrankings. Legislative staff based their initial evaluation on the following list: US News and World Report, Forbes, Kiplinger, Washington Monthly, Center for Measuring University Performance, Times Higher Education World University Rankings, QS World University Ranking, and the Academic Ranking of World Universities.

Freshman Retention Rate (Full-time, FTIC) as reported annually to the Integrated Postsecondary Education Data System (IPEDS). The retention rates that are reported in the Board's annual Accountability reportare preliminary because they are based on student enrollment in their second fall term as reported by the 28th calendar day following the first day of class. When the Board of Governors reports final retention rates to IPEDS in the Spring (usually the first week of April), that data is based on the student enrollment data as reported after the Fall semester has been completed. The preliminary and final retention rates are nearly identical when rounded to the nearestwhole number.

6-year Graduation Rate (Full-time, FTIC) as reported annually to the Integrated Postsecondary Education Data System (IPEDS). The Board of Governors reports the preliminary graduation rates in the annual Accountability report, and 'final' graduation rates to IPEDS in the beginning of February. The final rates are usually the same as the preliminary rates but can be slightly higher ( $1 \%-2 \%$ points) due to cohortadjustments for specific, and rare, exemptions allowed by IPEDS. 
National Academy
Memberships

\section{Total Annual Research}

Expenditures (\$M)

(Science \& Engineering only)
National Academy Memberships held by faculty as reported by the Center for Measuring University Performance in the Top American Research Universities (TARU) annual report.

Total Annual Research Expenditures in Diversified Non-Medical Sciences (\$M) (Science \& Engineering only)

Total Science \& Engineering Research Expenditures, including federal research expenditures, of $\$ 200$ million or more, as reported annually by the National Science Foundation (NSF).

Total S\&E research expenditures in non-medical sciences as reported by the NSF. This removes medical sciences funds ( $9 F \& 12 F$ in HERD survey) from the total S\&E amount.

The NSF identifies 8 broad disciplines within Science \& Engineering (Computer Science,

National Ranking in S.T.E.M. Engineering, Environmental Science, Life Science, Mathematical Sciences, Physical Sciences, Research Expenditures Psychology, Social Sciences). The rankings by discipline are determined by BOG staff using the NSF WebCaspar database.

Patents Awarded (over 3 year period)

Doctoral Degrees Awarded Annually

\section{Number of Post-Doctoral Appointees}

Endowment Size(\$M)
Total patents awarded by the United States Patent and Trademark Office (USPTO) for the most recent3-year period. Due to a year-lag in published reports, Board of Governors staff query the USPTO database with a query thatonly counts utility patents:"(AN/"University Name" AND ISD/20100101->20131231 ANDAPT/1)".

Doctoral degrees awardedannually, as reported annually in the Board of Governors Accountability Report Note: per legislative workpapers, this metric does not include Professional degrees.

The number of Postdoctoral Appointees awarded annually, as reported in the TARU annual report. This data is based on National Science Foundation/National Institutes of Health annual Survey of Graduate Students and Postdoctorates in Science and Engineering (GSS).

This data comes from the National Association of College and University Business Officers (NACUBO) and Commonfund Institute's annual report of Market Value of EndowmentAssets which, due to timing, may release the nextfiscal year's data after the Board of Governors Accountability reportis published. 


\section{Goals Common to All Universities}

\section{Academic Quality}

Avg. SAT Score (for 3 subtests)

An average weighted grade pointaverage of 4.0 or higher and an average SAT score of 1800 or higher for fall semester incoming freshmen, as reported annually in the admissions data that universities submit to the Board of Governors. This data includes registered FTIC (student type='B','E') with an admission action of admitted or provisionally admitted ('A','P','X').

\section{Avg. HS GPA} The average HS GPA for Admitted \& Registered FTIC and early admit(B,E) students.

Professional/Licensure Exam First-time Pass Rates Max score is 5.0 .

The number of exams with first-ime pass rates above and below the national or state average, as reported in the 2012-13 Accountability report, including: Nursing, Law, Medicine (3 subtests), Veterinary, Pharmacy, Dental (2 subtests), Physical Therapy, and Occupational Therapy.

Operational Efficiency

Freshman Retention Rate

The percentage ofa full-ime, first-time-in-college (FTIC) undergraduate cohort(entering in fall term or summer continuing to fall) that is still enrolled or has graduated from the same institution in the following fall term as reported in the 2012-13 Accountability report(table 4B) - see link.

As reported in the 2012-13 Accountability report(table 4D), First-ime-in-college (FTIC) cohortis defined as undergraduates entering in fall term (or summer continuing to fall) with fewer than 12

FTIC Graduation Rates In 4 years (or less) In 6 years (or less)

\section{AA Transfer Graduation Rates} In 2 years (or less) In 4 years (or less)

\section{Average Time to Degree (for FTIC)}

\section{Return on Investment}

Bachelor's Degrees Awarded

Percent of Bachelor's

Degrees in STEM

Graduate Degrees Awarded

Percent of Graduate Degrees in STEM

Annual Gifts Received (\$M)

Endowment (\$M) hours earned since high school graduation. The rate is the percentage of the initial cohortthat has either graduated fromor is still enrolled in the same institution by the fourth or sixth academic year. Both full-time and part-ime students are used in the calculation. The initial cohortis revised to remove students, who have allowable exclusions as defined by IPEDS, from the cohort.

As reported in the 2012-13 Accountability report(table 4E), AA Transfer cohortis defined as undergraduates entering in the fall term (or summer continuing to fall) and having earned an AA degree froman institution in the Florida College System. The rate is the percentage of the initial cohortthat has either graduated from or is still enrolled in the same institution by the second or fourth academic year. Both full-time and part-ime students are used in the calculation. The initial cohortis revised to remove students, who have allowable exclusions as defined by IPEDS, from the cohort.

This metric is the number of years between the start date (using date of most recentadmission) and the end date (using the last month in the term degree was granted) for a graduating class of first-time, single-major baccalaureates in 120 credit hour programs within a (Summer, Fall, Spring) year.

This is a count of baccalaureate degrees awarded as reported in the 2012-13 Accountability Report(table 4G).

The percentage ofbaccalaureate degrees that are classified as STEM by the Board of Governors in the SUS programinventory as reported in the 2012-13 Accountability Report(table 4H).

This is a count of graduate degrees awarded as reported in the 2012-13 Accountability Report (table 5B).

The percentage of baccalaureate degrees that are classified as STEM by the Board of Governors in the SUS program inventory as reported in the 2012-13 Accountability Report(table 5C).

As reported in the Council for Aid to Education's Voluntary SupportofEducation (VSE) survey in the section entitled "Gitt Income Summary," this is the sum of the presentvalue of all gitts (including outright and deferred gifts) received for any purpose and fromall sources during the fiscal year, excluding pledges and bequests. (There's a deferred gitt calculator at www.cae.org/vse.) The presentvalue of non-cash gitts is defined as the tax deduction to the donor as allowed by the IRS.

Endowmentvalue at the end of the fiscal year, as reported in the annual NACUBO Endowment Study (changed to the NACUBO-Common Fund Study of Endowments in 2009). 
Goals Specific to Research Universities

Academic Quality

Awards include: American Council of Learned Societies (ACLS) Fellows, Beckman Young Investigators, Burroughs Wellcome Fund Career Awards, Cotrell Scholars, FulbrightAmerican Scholars, Getty Scholars in Residence, Guggenheim Fellows, Howard Hughes Medical Institute Investigators, Lasker Medical Research Awards, MacArthur Foundation Fellows, Andrew W. Mellon Foundation Distinguished AchievementAwards, National Endowmentfor

Faculty Awards the Humanities (NEH) Fellows, National Humanities Center Fellows, National Institutes of Health (NIH) MERIT, National Medal of Science and National Medal of Technology, NSF CAREER awards (excluding those who are also PECASE winners), Newberry Library Longterm Fellows, Pew Scholars in Biomedicine, Presidential Early Career Awards for Scientists and Engineers (PECASE), RobertWood Johnson Policy Fellows, Searle Scholars, Sloan Research Fellows, Woodrow Wilson Fellows. As reported by the Top American Research Universities - see link.

The number of National Academy members included in the National Academy of Sciences,

National Academy Members

Number of Post-Doctoral appointees

Number of Science \& Engineering Disciplines nationally ranked in Top 100 for research expenditures

Return on Investment

Total Research Expenditures (\$M)

Science \& Engineering
Research Expenditures in
non-medical/health
sciences
Percent of R\&D Expenditures
funded from External
Sources

Patents Issued

Licenses/Options Executed

\section{Licensing Income Received (\$M)}

\section{Number of Start-up Companies} National rank is higher than predicted by Financial Resources Ranking based on US News \& World Report

Research Doctoral Degrees Awarded
National Academy of Engineering, and the Institute of Medicine. As reported by the Top American Research Universities - see link.

As submitted to the National Science Foundation Survey of Graduate Students and

Postdoctorates in Science \& Engineering (also known as the GSS) - see link.

The number of Science \& Engineering disciplines the university ranks in the top 100 (for public and private universities) based on the National Science Foundation's annual survey for R\&D expenditures, which identifies 8 broad disciplines within Science \& Engineering (Computer Science, Engineering, Environmental Science, Life Science, Mathematical Sciences, Physical Sciences, Psychology, and Social Sciences). Historically NSF provided these rankings (see tables 45-61 at link), but now data must be queried via WebCASPAR - see link.

Total expenditures for all research activities (including non-science and engineering activities) as reported in the National Science Foundation annual survey of Higher Education Research and Development(HERD).

This metric reports the Science \& Engineering total R\&D expenditures minus the research expenditures for medical sciences as reported by the National Science Foundation. Historically NSF provided these data (see link, table 36 minus table 52), butnow data must be queried via WebCASPAR.

This metric reports the amount of research expenditures that was funded from federal, private industry and other (non-state and non-institutional) sources.

Source: National Science Foundation annual survey ofHigher Education Research and Development(HERD).

The number of patents issued in the fiscal year as reported in the 2011-12 Accountability Report(table 6A).

Licenses/options executed in the fiscal year for all technologies as reported in the 2011-12 Accountability Report(table 6A).

License issue fees, payments under options, annual minimums, running royalties, termination payments, amount of equity received when cashed-in, and software and biological material end-user license fees of $\$ 1,000$ or more, butnot research funding, patent expense reimbursement, valuation of equity not cashed-in, software and biological material end-user license fees of less than $\$ 1,000$, or trademark licensing royalties from university insignia. Data as reported in the 2012-13 Accountability Report(table 6A).

The number of start-up companies that were dependentupon the licensing of University technology for initiation as reported in the 2012-13 Accountability Report (table 6A).

This metric compares the overall national university ranking to the financial resources rankas reported by the US News and World report

The number of research doctoral degrees awarded annually as reported in the 2012-13 Accountability Report(table 5B). 


\section{Professional Doctoral Degrees Awarded}

The number of professional doctoral degrees awarded annually as reported in the 2012-13 Accountability Report(table 5B).

\section{Student Debt Summary}

\section{Percent of Bachelor's Recipients with Debt}

This is the percentage ofbachelor's graduates in a given academic year who entered the university as a first-time-in-college (FTIC) studentand who borrowed through any loan programs (institutional, state, Federal Perkins, Federal Stafford Subsidized and unsubsidized, private) that were certified by your institution - excludes parentloans.

Source: Common Dataset (H4).

This is the average amountof cumulative principal borrowed (fromany loan program certified by the institution) for each native, FTIC bachelor's recipientin a given academic year that graduated with debt - see metric definition above. This averagedoes NOT include students who did not enter a loan program that was certified by the institution. Source: Common Dataset (H5).

Student loan cohort default rate (CDR) data includes undergraduate and graduate students, and refers to the three federal fiscal year period when the borrower enters repaymentand ends on the second fiscal year following the fiscal year in which the borrower entered repayment Cohortdefault rates are based on the number of borrowers who enter repayment, not the number and type of loans that enter repayment. A borrowerwith multiple loans from the same school whose loans enter repaymentduring the same cohort fiscal year will be included in the formula only once for that cohortfiscal year. Defaultrate debtincludes: Federal Stafford Loans, and Direct Stafford/Ford Loans - for more information see:

http://ifap.ed.gov/DefaultManagement/CDRGuideMaster.html.

\begin{tabular}{|c|c|c|c|}
\hline \multicolumn{4}{|c|}{ Three Year CDR } \\
\hline $\begin{array}{l}\text { Cohort } \\
\text { Fiscal } \\
\text { Year }\end{array}$ & $\begin{array}{c}\text { Year } \\
\text { Published }\end{array}$ & $\begin{array}{l}\text { Borrowers in the Numerator } \\
\text { Borrowers in the Denominator }\end{array}$ & $\begin{array}{l}\frac{\text { 3-Yr Time Period }}{\text { (Numerator) }} \\
\text { 1-Yr Time Period } \\
\text { (Denominator) }\end{array}$ \\
\hline 2009 & 2012 & $\begin{array}{l}\text { Borrowers who entered repayment in } 2009 \\
\text { and defaulted in } 2009,2010 \text { or } 2011 \\
\text { Borrowers who entered repayment in } 2009\end{array}$ & $\frac{10 / 01 / 2008 \text { to } 9 / 30 / 2011}{10 / 01 / 2008 \text { to } 9 / 30 / 2009}$ \\
\hline 2010 & 2013 & $\begin{array}{l}\text { Borrowers who entered repayment in } 2010 \\
\text { and defaulted in } 2010,2011 \text { or } 2012 \\
\text { Borrowers who entered repayment in } 2010\end{array}$ & $\frac{10 / 01 / 2009 \text { to } 9 / 30 / 2012}{10 / 01 / 2009 \text { to } 9 / 30 / 2010}$ \\
\hline 2011 & $2014^{*}$ & $\begin{array}{l}\text { Borrowers who entered repayment in } 2011 \\
\text { and defaulted in } 2011,2012 \text { or } 2013 \\
\text { Borrowers who entered repayment in } 2011\end{array}$ & $\frac{10 / 01 / 2010 \text { to } 9 / 30 / 2013}{10 / 01 / 2010 \text { to } 9 / 30 / 2011}$ \\
\hline 2012 & 2015 & $\begin{array}{l}\text { Borrowers who entered repayment in } 2012 \\
\text { and defaulted in } 2012,2013 \text { or } 2014 \\
\text { Borrowers who entered repayment in } 2012\end{array}$ & $\frac{10 / 01 / 2011 \text { to } 9 / 30 / 2014}{10 / 01 / 2011 \text { to } 9 / 30 / 2012}$ \\
\hline 2013 & 2016 & $\begin{array}{l}\text { Borrowers who entered repayment in } 2013 \\
\text { and defaulted in } 2013,2014 \text { or } 2015 \\
\text { Borrowers who entered repayment in } 2013\end{array}$ & $\frac{10 / 01 / 2012 \text { to } 9 / 30 / 2015}{10 / 01 / 2012 \text { to } 9 / 30 / 2013}$ \\
\hline 2014 & 2017 & $\begin{array}{l}\text { Borrowers who entered repayment in } 2014 \\
\text { and defaulted in } 2014,2015 \text { or } 2016 \\
\text { Borrowers who entered repayment in } 2014\end{array}$ & $\frac{10 / 01 / 2013 \text { to } 9 / 30 / 2016}{10 / 01 / 2013 \text { to } 9 / 30 / 2014}$ \\
\hline 2015 & 2018 & $\begin{array}{l}\text { Borrowers who entered repayment in } 2015 \\
\text { and defaulted in } 2015,2016 \text { or } 2017 \\
\text { Borrowers who entered repayment in } 2015\end{array}$ & $\frac{10 / 01 / 2014 \text { to } 9 / 30 / 2017}{10 / 01 / 2014 \text { to } 9 / 30 / 2015}$ \\
\hline
\end{tabular}

